\title{
Authenticity, Perceived Value and Loyalty in Marine Tourism Destinations: The Case of Zhoushan, Zhejiang Province, China
}

\author{
Yongjun Su, Junjie $\mathrm{Xu} * \mathbb{D}$, Marios Sotiriadis and Shiwei Shen \\ Joint Institute of Ningbo University and University of Angers/Sino-European Institute of Tourism and Culture, \\ Ningbo University, Ningbo 315211, China; suyongjun@nbu.edu.cn or suyongjun7312@163.com (Y.S.); \\ sotiriadis@nbu.edu.cn (M.S.); shiwei_shen@163.com (S.S.) \\ * Correspondence: 13776013414@163.com; Tel.: +86-137-3615-5289
}

Citation: Su, Y.; Xu, J.; Sotiriadis, M.; Shen, S. Authenticity, Perceived Value and Loyalty in Marine Tourism

Destinations: The Case of Zhoushan, Zhejiang Province, China. Sustainability 2021, 13, 3716. https:/ / doi.org/10.3390/su13073716

Academic Editor: Alastair M. Morrison

Received: 18 February 2021

Accepted: 23 March 2021

Published: 26 March 2021

Publisher's Note: MDPI stays neutral with regard to jurisdictional claims in published maps and institutional affiliations.

Copyright: (c) 2021 by the authors. Licensee MDPI, Basel, Switzerland. This article is an open access article distributed under the terms and conditions of the Creative Commons Attribution (CC BY) license (https:// creativecommons.org/licenses/by/ $4.0 /)$.

\begin{abstract}
A very good understanding and knowledge about the tourists' perceptions are of critical importance for the management and marketing of tourism destinations and sites of all types. The aim of this study was to investigate the perceived authenticity and its relationship with perceived value and loyalty of tourists in the context of marine tourism. First, the study proposed a research model based on the conceptual foundations of authenticity, perceived value and loyalty. The suggested model was then tested by means of a quantitative survey conducted in Zhoushan, one of the most popular Chinese marine tourism destinations. The study's findings revealed that the object-based authenticity and interpersonal authenticity significantly affected perceived value and loyalty of tourists, and the perceived value partly mediated the relationship between authenticity and loyalty. The article is completed by discussing the theoretical and managerial implications.
\end{abstract}

Keywords: marine tourism destination; perceived authenticity; perceived value; loyalty

\section{Introduction}

Tourism literature defines the concept of authenticity as genuineness or realness of artifacts or events, as well as a human attribute signifying being one's true self or being true to one's essential nature. Scholars proposed that the concept of authenticity can be split into 'object-based authenticity' and 'existential authenticity'. The former is about tourists' perception about objects, while the latter refers to tourists' perception about "themself" when they are on holidays/trips [1]. From the perspective of objectivism, early scholars argued that authenticity is an innate characteristic of tourism objects, and as such, can be measured with objective standards [2-4]. However, this conceptualization has become less popular in recent literature because it has the drawback to oversimplify the meaning of authenticity. Scholars adopting constructivism believe that objective authenticity is no longer applicable to tourism destinations or contexts having a high degree of commodification and commercialization [5], nor does it reflect the contemporary quest of tourists for authenticity, a kind of symbolic authenticity [6]. Therefore, they proposed that authenticity has symbolic meaning reflected into tourism objects by tourists or tourism suppliers through their subjective imagination and preferences [1]. This research stream has gradually reached a consensus that the concept of 'constructivist authenticity' is more suitable for conducting research in tourism field and contexts [7-10].

Adding the dimension of complexity to authenticity, scholars proposed the concept of 'existential authenticity' to capture tourists' desire to escape from their everyday life and their pursuit of high-quality interpersonal communication [11,12]. Wang [1] suggests that existential authenticity encompasses intrapersonal and interpersonal dimensions. The former refers to the sensory enjoyment and self-realization of individuals in performing tourism activities, whereas the latter refers to the natural and equal interpersonal interaction between tourists and other persons in tourism destination [1]. It is worth noticing that the over-generalization of existential authenticity should be avoided [13-16] because not all 
tourism experiences can enhance tourists in attaining a state of "authentic being" [17]. In this regard, Kirillova found that the influence of existential authenticity in the settings of cultural heritage, sightseeing, theme parks, backpacking, and volunteer tourism is much more conspicuous and significant than in other tourism contexts [18].

Despite the above valuable contributions and progress made in this research field, there is still a need for a better knowledge and in-depth understanding of the impact of authenticity on tourists' perceived value. First, extant literature has examined the relationship between authenticity and perceived value and found that object-based authenticity and existential authenticity positively affects tourists' perceived value in the tourism field in general $[19,20]$. However, previous studies have failed to address the issue of distinction between intrapersonal and interpersonal authenticity. Consequently, they have not examined their respective influence on perceived value. Intrapersonal authenticity is based on tourists' perception of their own emotions, whereas interpersonal authenticity is based on tourists' perception of interpersonal communication [7]. Therefore, these two concepts should be considered and examined separately. This is a knowledge gap addressed by our study.

A second gap in this research field is the influence of authenticity on loyalty, on which there are conflicting views. Some scholars found that the object-based authenticity positively affects tourists' loyalty while existential authenticity has no significant influence $[9,21]$. However, other scholars suggested conflicting findings $[8,15,16]$. Likewise, the influence of existential authenticity on loyalty is equally under-researched. Hence, there is a need for additional studies examining these relationships in different contexts to gain a better, in-depth understanding. Therefore, this study is attempting to address the above knowledge gaps by examining the relationship between authenticity, perceived value, and tourist loyalty in a comprehensive manner, based on a unified theoretical framework. More importantly, this study attempts to achieve a better understanding of object-based authenticity from the constructivist perspective and distinguishes two different dimensions of existential authenticity.

Against this background, our study considers the topic within the context of marine tourism. The main purpose is, therefore, to explore how tourists' perception of authenticity affects the evaluation of their experience and loyalty to tourism destinations. To achieve the research aim, the study first proposed a research model for the relationship between the three constructs, namely authenticity, perceived value and loyalty. The suggested research model was then tested and validated by means of an explorative survey in three popular marine tourism sites in Zhoushan Archipelago, Southeast China. It is believed that the study's findings should provide valuable academic contribution to the research of authenticity and put forward effective managerial implications for the sustainable development of marine tourism destinations.

\section{Literature Review}

\subsection{Object-Based Authenticity and Existential Authenticity in Tourism Research}

Object-based authenticity can be understood from two perspectives, namely objectivism and constructivism [1]. Initially, scholars considered the authenticity of tourism objects from the perspective of objectivism, proposing that authenticity could be measured by objective criteria [2-4]. Then, academic research abandoned this approach due to two reasons: (i) the culture of tourist destinations could easily lose its original meaning and thus, associated characteristics after "commercialization", and (ii) authenticity cannot be easily assessed based on objective criteria [22,23]. Therefore, this objectivist perspective was criticized of oversimplifying authenticity, rendering the concept inapplicable to tourism research [24].

Constructive authenticity was introduced to capture perceived authenticity reflected into tourism objects by tourists or tourism suppliers in terms of their expectations, preferences, and beliefs. It is believed that constructive authenticity is a socially-constructed concept determined by tourists' perception which is relative, evolutive, changeable, and 
contextual [14,25-27]. Studies suggested that tourists' perception of authenticity is based on tangible and intangible factors. The former includes exterior features and interior decoration of buildings, as well as surrounding environment and ambience in tourism attractions/destinations [28-31]. The intangible factors are mainly customs and traditions, such as clothing, food, art, stories, festivals and cultural rituals. It is believed that constructivism perspective constitutes a valuable contribution to better explain and understand the relationship between commercialization/commodification and object-based authenticity [32].

On the contrary, the perception of existential authenticity is the result of tourism activities. Brown describes this concept as a state of being that is activated by tourists when enjoying a good experience [33]. Existential authenticity encompasses two dimensions, i.e., intrapersonal and interpersonal [7]. According to Wang [1], the former further includes two sub-dimensions, that is "bodily feelings" - the sensory enjoyment of individuals in the tourist process-and "self-making". The latter dimension-interpersonal authenticity-refers to the close relationship that tourists feel and the interpersonal relationship between tourists [1]. According to Knudsen, during a trip, existential authenticity can only be experienced in a limited number of moments [17]. Other scholars suggested that tourists can experience existential authenticity, particularly within the context of heritage tourism [28,34,35], of pilgrimage [36-38], of volunteer tourism [39], and of sightseeing [40] because these activities/settings enhance tourists to better feel their identity and value in history and environment, and thus create an authentic self $[10,15]$.

The relationship between object-based authenticity and existential authenticity has been explored by some studies. It was found that object-based authenticity had significant influence on an existential one [8,10]. For instance, the study of Yi [28] found that objectbased authenticity significantly affects the intrapersonal one in heritage tourism sites but does not influence the interpersonal dimension. However, marine tourism, as a tourism context and setting combining both cultural and natural elements, has received little attention and is under-researched. Therefore, this study focuses on exploring authenticity in the context of marine tourism.

\subsection{Perceived Value}

The concept of perceived value is crucial to understanding the tourism service experience $[41,42]$ and is defined as the consumer's overall assessment of the net worth of a product (or service); that is, the difference between the perceived sacrifices and the received benefits [43]. Extant literature explored the meaning and dimensions of perceived value mainly in tourism and retail industries and has mainly proposed two dimensions, namely functional value and emotional value [44-47]. The former refers to the quality of products and services, while emotional value is related to the emotion and feelings in tourism experience [48,49].

Recently, the concept of perceived value has been adopted in exploring tourist behavior and experience. Some tourism scholars have studied the relationship between experience quality, perceived value, satisfaction and behavioral intention using structural equation models. More particularly, they attempted to determine the positive relationship between authenticity and perceived value $[19,31]$ and the role played by perceived value in mediating the relationship between authenticity and the tourists' behavioral intention $[20,50]$. However, such endeavors are very limited. Our study examines the relationship between object-based authenticity, existential authenticity and perceived value in a more comprehensive/integrated way by distinguishing the two dimensions of existential authenticity and considering them as separate research constructs.

\subsection{Tourist Loyalty}

Previous studies examined the concept of loyalty suggesting three directions, namely attitudinal, behavioral and composite loyalty. Attitudinal loyalty is described as commitment to the continuous and repeated purchase of products or services, namely the 
willingness to repurchase [51-53]. Behavioral loyalty is defined as patronage and recommendation [54], while composite loyalty is the combination of attitudinal and behavioral loyalty [53]. Intention to revisit and recommendation intention are regarded as the two most important indicators to assess tourist loyalty [54]. As for the process of loyalty, this is consisted of three stages, namely cognitive, emotional and conative stage [55]. Cognitive loyalty is formed up based on product information available to consumers. This stage, considered the weakest form of loyalty, is particularly sensitive to price change [56-59]. Second, the emotional loyalty is developed based on consumers' attitude towards products, the established relationship between consumers and products. Finally, as the strongest predictor of consumers' behavioral loyalty [59], conative loyalty refers to tourists' emotional loyalty extended to other brands of a certain category of services/products out of their satisfaction with the already-used brands.

A very limited number of studies have found that object-based authenticity and existential authenticity positively affected tourist loyalty. However, these studies have not provided a clear conclusion about the relationship between authenticity and loyalty. Some studies found that object-based authenticity has a greater positive impact on tourist loyalty [42], while others revealed that existential authenticity better predicts loyalty behavior $[60,61]$. Therefore, this study attempts to explore the relationship between objectbased authenticity, existential authenticity and tourist loyalty in an integrated manner.

\section{Developing Research Hypotheses and Model}

\subsection{Authenticity and Perceived Value}

With the aim to better understand the relationship between authenticity, perceived value and loyalty, this study argues that tourists' quest for authenticity can be regarded as a tourist motivation. As Heidegger stressed, tourists seek experiences that counter the emptiness of everyday life in modern societies and provide them an opportunity to be authentic [12]. As a result, when tourists perceive the authenticity of tourism activity and an authentic self while on trip/holidays, their motivation is satisfied and they are more likely to feel the trip/holiday's value $[20,31,50]$. Therefore, it can be assumed that there is an intrinsic relationship between authenticity and perceived value.

Previous studies reported the positive impact of authenticity on perceived value and customer loyalty in tourism contexts [57,62-65]. However, few studies indicated that existential authenticity had a positive influence on perceived value but did not report the differential impacts of intrapersonal authenticity and interpersonal authenticity on perceived value $[19,20]$. Hence, this study postulates the following hypotheses:

Hypothesis 1a (H1a). Object-based authenticity $(O B A)$ positively influences perceived value (PV). Hypothesis $\mathbf{1 b}$ (H1b). Intrapersonal authenticity (IEXA) positively influences perceived value $(P V)$. Hypothesis 1c (H1c). Interpersonal authenticity (EEXA) positively influences perceived value (PV).

\subsection{Authenticity and Loyalty}

Since tourists are motivated to travel in search of authenticity, the tourist experience assessed as authentic will lead to loyalty to the destination/attraction. Meleddu argues that cognitive loyalty is the first stage of loyalty, which is mainly related to the attributes, information or knowledge of objects [55]. It is suggested that tourists' subjective perception of tourist objects can affect their loyalty to a certain extent. In addition, intrapersonal authenticity is related to tourists' emotional experience, and tourist loyalty is based on emotional factors. Therefore, it can be assumed that there is a relationship between the two factors; that is, loyalty can be influenced by a high-quality emotional experience $[8,9,28]$. Moreover, tourists may be more open to activities in destination when they get close to their families, local persons and other tourists. Therefore, interpersonal authenticity may also affect loyalty $[7,10]$. Based on these suggestions, it is argued that there is a relationship between the three constructs, namely object-based authenticity, existential authenticity and loyalty. Therefore, this paper proposes the following three hypotheses: 
Hypothesis 2a (H2a). Object-based authenticity positively influences loyalty (LOY).

Hypothesis $\mathbf{2 b}$ (H2b). Intrapersonal authenticity positively influences loyalty (LOY).

Hypothesis 2c (H2c). Interpersonal authenticity positively influences loyalty (LOY).

\subsection{Perceived Value and Loyalty}

Perceived value can be considered in terms of functional value and emotional value. Previous studies suggested that the quality of tourism services, the behavior of tourism suppliers, as well as their efficiency and effectiveness have a significant influence on tourists' evaluation of destination $[53,63]$. Lee, Lee, and Choi emphasized that emotional factors promote differentiation, value, satisfaction, trust and loyalty by satisfying human needs [66]. Therefore, it can be assumed that perceived value has a significant impact on loyalty.

Some studies in the broader tourism context reported that perceived value influences loyalty $[31,43,49]$. This study examines the relationship between perceived value and loyalty in the context of marine tourism. Therefore, the following hypothesis is advanced:

Hypothesis 3a (H3a). Perceived value positively influences loyalty.

\subsection{The Mediating Role of Perceived Value}

An additional factor explored by this study is the mediating effect of perceived value (PV) on the relationship between three types of authenticity (OBA, IEXA and EEXA) and loyalty. Under the condition that the tourism objects and activities can convey a kind of authenticity to tourists, tourists' perceived value will be enhanced, thus leading to increase the tourists' loyalty [31,49]. Therefore, it can be assumed that perceived value mediates the relationship between authenticity and loyalty. Therefore, this paper proposes three hypotheses about the mediating effect of PV:

Hypothesis 4a (H4a). Object-based authenticity positively influences loyalty through perceived value $(P V)$.

Hypothesis $4 \mathbf{b}$ (H4b). Intrapersonal authenticity positively influences loyalty through perceived value $(P V)$.

Hypothesis 4c (H4c). Interpersonal authenticity positively influences loyalty through perceived value $(P V)$.

Therefore, the research model is proposed based on the discussions of all the research hypotheses (see Figure 1).

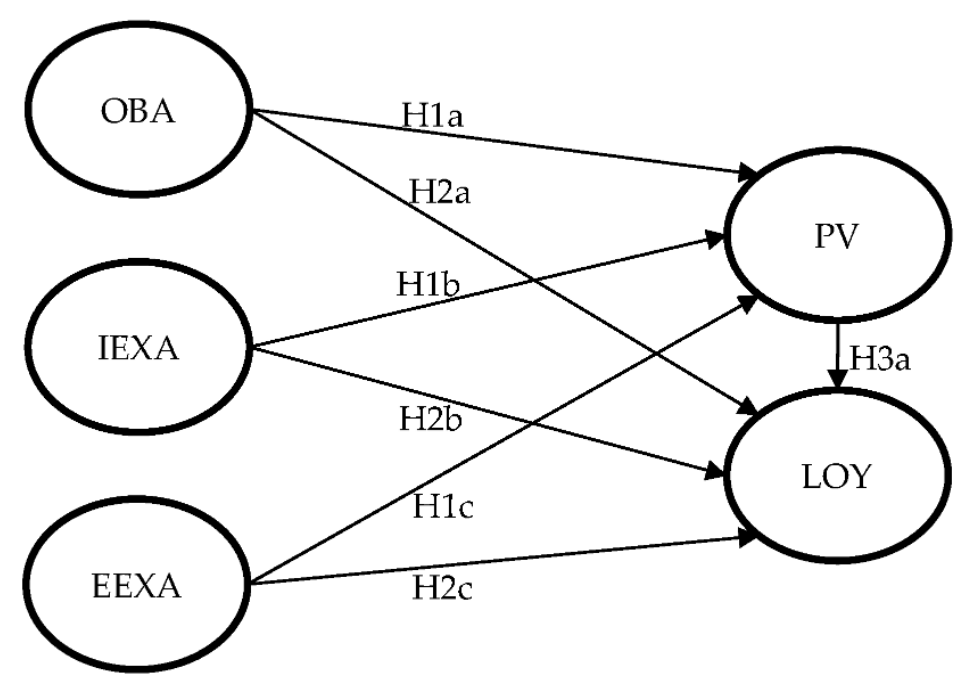

Figure 1. The proposed research model. 


\section{Materials and Methods}

The study's aim was to investigate the effect of authenticity on tourists' perceived value and loyalty. The above suggested research model proposes three factors as antecedents of the value of tourism experience as perceived by tourists (PV). The latter (PV) is a mediating factor impacting the tourists' loyalty towards a destination or site.

The suggested research model was empirically tested by means of a quantitative/ explorative conducted in Zhoushan Archipelago, Zhejiang Province, China. The main elements of this empirical investigation are presented hereafter.

\subsection{Research Design}

This research selected as study areas three tourist islands in Zhoushan Archipelago, Zhejiang Province (SE China), i.e., Mount Putuo, Zhujiajian and Peach Blossom Island. This choice was made based on two main criteria, namely: (i) the diversified marine landscapes (e.g., marine cultural relics, marine historical places, marine facilities and artistic landscape); and (ii) high visitation, high volume of passengers during the peak season (July to October). All respondents-tourists visiting the three islands-were selected by random sampling method.

\subsection{Instrument Development}

The research instrument (survey questionnaire) consisted of 5 research constructs having a number of measurement items as follows: Object-based authenticity (OBA) with 7 items; Intrapersonal authenticity (IEXA) with 3 items; Interpersonal authenticity (EEXA) measured with 3 items; Perceived value (PV) with 5 items; and Loyalty (LOY) with 3 items. The measurement items of OBA were designed according to the study by Yi [10], and were adapted by taking into account the specific empirical context. Measurement items for IEXA and EEXA were adopted from Yi and Kolar and Zabkar [8], items for PV were adopted from Fu [49], and the items for LOY are those suggested by Zhou [9]. All items were measured using a 7-points Likert scale, 1-Strong disagreement to 7-Strong agreement. The initially drafted questionnaire went through a pilot test. Three experienced tourism researchers were asked to examine and assess the content and provided feedback on and suggestions for improvement. The final form of the questionnaire was used to collect data.

\subsection{Data Collection}

Data collection was conducted respectively in August 2020 and March 2021 by distributing questionnaires in tourist attractions. All respondents were informed in advance of the study's purpose and assured that their answers were anonymous and voluntary. In total, 475 questionnaires were completed; however, 408 were duly filled in and suitable for statistical analyses.

The respondents' sample is considered as representative (Table 1). Respondents were fairly distributed in terms of gender ( $51.7 \%$ male and $48.0 \%$ female). As for the age, $12.7 \%$ are under $25 ; 35.8 \%$ are between 26 and 35; 33.6\% are between 36 and 45 . Regarding the education level, most of the respondents have already completed their studies or are university students. Most of the respondents traveled independently and were from Zhejiang Province and neighboring provinces. 
Table 1. Sample profile.

\begin{tabular}{|c|c|c|c|}
\hline Variables & Category & $\mathbf{N}$ & Percentage $(\%)$ \\
\hline \multirow{3}{*}{ Gender } & Male & 211 & 51.7 \\
\hline & Female & 196 & 48.0 \\
\hline & Missing & 1 & 0.2 \\
\hline \multirow{5}{*}{ Age Group } & $\leq 25$ & 52 & 12.7 \\
\hline & $26-35$ & 146 & 35.8 \\
\hline & $36-45$ & 137 & 33.6 \\
\hline & $46-55$ & 64 & 15.7 \\
\hline & $\geq 56$ & 9 & 2.2 \\
\hline \multirow{8}{*}{ Profession } & Government staff & 38 & 9.3 \\
\hline & Professional/technical personnel & 43 & 10.5 \\
\hline & Staff & 97 & 23.8 \\
\hline & Businessman & 68 & 16.7 \\
\hline & Technicians/laborer & 35 & 8.6 \\
\hline & Waiter/salesmen & 30 & 7.4 \\
\hline & Students & 46 & 11.3 \\
\hline & Other professions & 51 & 12.5 \\
\hline \multirow{5}{*}{ Education } & Middle school and below & 32 & 7.9 \\
\hline & High school & 76 & 18.6 \\
\hline & Junior College & 101 & 24.8 \\
\hline & Bachelor & 138 & 33.8 \\
\hline & Master and Doctorate & 61 & 15.0 \\
\hline \multirow{5}{*}{$\begin{array}{l}\text { Tourists' permanent } \\
\text { residence }\end{array}$} & Anhui Province & 34 & 8.3 \\
\hline & Jiangsu Province & 66 & 16.2 \\
\hline & Shanghai Special Municipality & 52 & 12.7 \\
\hline & Zhejiang Province & 142 & 34.8 \\
\hline & Other provinces & 114 & 27.9 \\
\hline \multirow{5}{*}{ Travel mode } & Package tour & 42 & 10.3 \\
\hline & Free tour & 223 & 54.7 \\
\hline & Tour with travel companion & 64 & 15.7 \\
\hline & Company organized tour & 43 & 10.5 \\
\hline & Other modes & 36 & 8.8 \\
\hline
\end{tabular}

\section{Results: Data Analysis and Findings}

The software AMOS 24.0 was used to perform the statistical analyses; component reliability (CR) and convergent validity (AVE) of the measures were calculated through a confirmatory factor analysis (CFA). After dropping items with low factor loading, we retained the remaining 16 items. We adopted structural equation models to check construct validity and reliability and test hypotheses; according to Nunnally, 408 observations were sufficient for this statistical model testing with 16 items [67]. Finally, the mediating effect was tested in AMOS 24.0 with 5000 bootstrapping resamples and the $95 \%$ biascorrected and percentile confidence interval (CI) method. The results are presented in the following subsections.

\subsection{Confirmatory Factor Analysis}

According to the two-step method suggested by Anderson and Gerbing (1988), a CFA, as a measurement model, should be conducted first to test the validity and reliability of measures [68]. Five constructs and 20 items were included in the research model. We then dropped several items with low factor loading and square multivariate correlation (SMC). The results are shown in Table 2. The final model contains 4 items for OBA, 3 items for IEXA, 3 items for EEXA, 3 items for PV and 3 items for LOY. As shown in Table 2, the factor loading of most items were above the 0.7 threshold. The factor loading of IEXA2 and PV3 were 0.687 and 0.656 respectively, which was not perfect but still acceptable. The indicator of SMC should not be lower than 0.36 [69], thus the reliability of all the 
items was acceptable. The construct reliability (CR) of each measure is higher than the suggested 0.7 cutoff point [69], indicating that the items for each measure are internally consistent (see Table 2). The AVE of each measure was above the 0.50 threshold, suggesting its good convergent validity (see Table 2). As in Table 3, the square root of AVE value of each measure is greater than the correlation coefficient between this measure and other measures, indicating sufficient discriminative validity [70].

Table 2. Results of the measurement model.

\begin{tabular}{|c|c|c|c|c|}
\hline Construct/Items & Loading & SMC & $\mathrm{CR}$ & AVE \\
\hline $\begin{array}{l}\text { Object-Based Authenticity (OBA) } \\
\text { I perceived the marine cultural relics to be original. } \\
\text { The marine historical sites embody marine history. } \\
\text { The local art is closely related to marine culture. } \\
\text { The folk customs are closely related to marine culture. }\end{array}$ & $\begin{array}{l}0.786 \\
0.771 \\
0.707 \\
0.721\end{array}$ & $\begin{array}{l}0.618 \\
0.594 \\
0.500 \\
0.520\end{array}$ & 0.834 & 0.558 \\
\hline $\begin{array}{c}\text { Intrapersonal Authenticity (IEXA) } \\
\text { My body was freed from the limitation of daily work/routine. } \\
\text { I tried to seek novel travel experiences to satisfy myself (IEXA2) } \\
\text { I feel immersed in the marine ambience. }\end{array}$ & $\begin{array}{l}0.924 \\
0.687 \\
0.757\end{array}$ & $\begin{array}{l}0.854 \\
0.472 \\
0.573\end{array}$ & 0.836 & 0.633 \\
\hline $\begin{array}{l}\text { Interpersonal Authenticity (EEXA) } \\
\text { I keep in touch with local people in a natural and friendly way. } \\
\text { I keep in touch with my family in a natural and friendly way. } \\
\text { I keep in touch with other tourists in a natural and friendly way. }\end{array}$ & $\begin{array}{l}0.814 \\
0.859 \\
0.762\end{array}$ & $\begin{array}{l}0.663 \\
0.738 \\
0.581\end{array}$ & 0.853 & 0.661 \\
\hline $\begin{array}{c}\text { Perceived Value }(\mathrm{PV}) \\
\text { I received excellent tourist service in this scenic spot. } \\
\text { Accommodation, transportation and shopping here are convenient. } \\
\text { I think the site is worth visiting. (PV3) }\end{array}$ & $\begin{array}{l}0.736 \\
0.886 \\
0.656\end{array}$ & $\begin{array}{l}0.542 \\
0.785 \\
0.430\end{array}$ & 0.807 & 0.586 \\
\hline $\begin{array}{l}\text { Loyalty (LOY) } \\
\text { I would like to visit this site again. } \\
\text { I would like to travel to similar sites. } \\
\text { I would like to recommend this site to others. }\end{array}$ & $\begin{array}{l}0.792 \\
0.735 \\
0.835\end{array}$ & $\begin{array}{l}0.627 \\
0.540 \\
0.697\end{array}$ & 0.831 & 0.621 \\
\hline
\end{tabular}

Note: $\mathrm{SMC}=$ Squared multiple correlation, $\mathrm{CR}=$ Composite reliability, AVE = Average variance extracted.

Table 3. Discriminant validity.

\begin{tabular}{ccccccc}
\hline & AVE & LOY & PV & EEXA & IEXA & OBA \\
\hline LOY & $\mathbf{0 . 6 2 1}$ & $\mathbf{0 . 7 8 8}$ & & & & \\
PV & $\mathbf{0 . 5 8 6}$ & 0.656 & $\mathbf{0 . 7 6 6}$ & & & \\
EEXA & $\mathbf{0 . 6 6 1}$ & 0.535 & 0.505 & $\mathbf{0 . 8 1 3}$ & & \\
IEXA & $\mathbf{0 . 6 3 3}$ & 0.272 & 0.256 & 0.363 & $\mathbf{0 . 7 9 6}$ & \\
OBA & $\mathbf{0 . 5 5 8}$ & 0.563 & 0.446 & 0.312 & 0.277 & $\mathbf{0 . 7 4 7}$ \\
\hline
\end{tabular}

Note: Square root of AVE > Inter-construct correlation. OBA = Object-based authenticity, IEXA = Intrapersonal authenticity, EEXA = Interpersonal authenticity, PV = Perceived value, LOY = Loyalty. The values in bold are square root of average variance extracted.

The indices for measurement model fit all suggest a sufficient model fit. $\chi^{2}$ is considerably influenced by sample size and a well-specified model could still be subject to rejection with a sufficiently large sample [5]. Baumgartner and Homburgthus recommended that researchers avoid over-reliance on $\chi^{2}$ statistic and instead report multiple fit indices representing different types of measures [71]. Following their suggestion, we report in Table 4 several fit indices. Among them, comparative fit index (CFI) is 0.960, goodness-of-fit index (GFI) is 0.941, Tucker-Lewis index (TLI) is 0.949 and NFI index is 0.931, all above the 0.9 threshold suggested by Bollen [72] and Hoyle [73]. Finally, root mean square error of approximation (RMSEA) is 0.056 , below the 0.08 upper bound [69]. All these results suggest a good model fit. 
Table 4. Model fit indices.

\begin{tabular}{cccccccc}
\hline$\chi^{2} / \mathbf{d f}$ & $\mathbf{P}$ & GFI & CFI & NFI & TLI & RMSEA & RMR \\
\hline 2.277 & 0.000 & 0.941 & 0.960 & 0.931 & 0.949 & 0.056 & 0.035 \\
\hline
\end{tabular}

\subsection{Structural Model and Hypothesis Testing}

All model fit indices (see Table 4) suggest a good fit between the collected data. Therefore, the structural model and hypothesis can be tested. The validity of the structural model was tested by applying a maximum likelihood method estimating the fit between the data and the proposed model containing five latent factors (OBA, IEXA, EEXA, PV, LOY). Figure 2 shows the structural model and path coefficients for links between latent factors. As shown in Table 5, H1a, H1c, H2a, H2c, H3a are supported, but $\mathrm{H} 1 \mathrm{~b}$ and $\mathrm{H} 2 \mathrm{~b}$ are rejected. The results show that OBA and EEXA significantly influence perceived value and loyalty, while the IEXA cannot affect tourists' perceived value and loyalty.

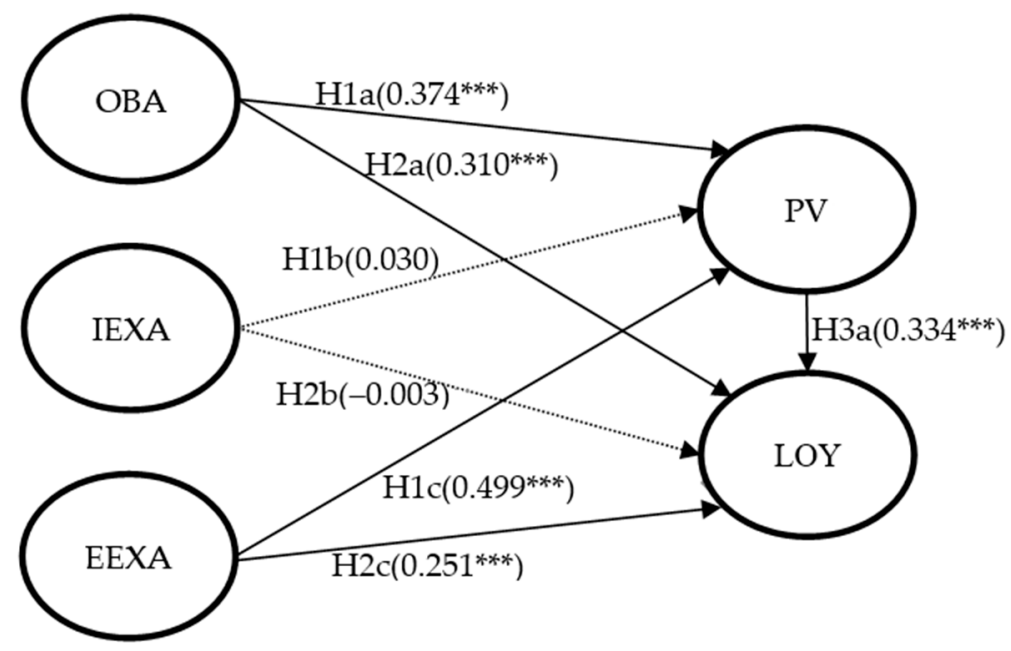

Figure 2. Structural equation model results. Note: ${ }^{* * *} p<0.001$. Significant means the value of $p$ is less than 0.05 .

Table 5. Hypothesis testing.

\begin{tabular}{ccccc}
\hline Path & Estimate & S.E. & P & Result \\
\hline OBA $\rightarrow$ PV (H1a) & 0.374 & 0.071 & $* * *$ & Supported \\
IEXA $\rightarrow$ PV (H1b) & 0.030 & 0.070 & 0.671 & Rejected \\
EEXA $\rightarrow$ PV (H1c) & 0.499 & 0.081 & $* * *$ & Supported \\
OBA $\rightarrow$ LOY (H2a) & 0.310 & 0.056 & $* * *$ & Supported \\
IEXA $\rightarrow$ LOY (H2b) & -0.003 & 0.051 & 0.953 & Rejected \\
EEXA $\rightarrow$ LOY (H2c) & 0.251 & 0.063 & $* * *$ & Supported \\
PV $\rightarrow$ LOY (H3a) & 0.334 & 0.055 & $* * *$ & Supported
\end{tabular}

Note: OBA = Object-based Authenticity, IEXA = Intrapersonal authenticity, EEXA = Interpersonal authenticity, $\mathrm{PV}=$ Perceived value, LOY $=$ Loyalty. ${ }^{* * *} p<0.001$.

\subsection{Testing for Mediating Effects of Perceived Value}

We tested the mediating effect of perceived value on the relationship between authenticity and loyalty. Different from previous studies, this study considered existential authenticity into two separate dimensions: the intrapersonal authenticity and the interpersonal authenticity to explore their separate impact on tourist experience.

We used AMOS to test the mediating effects with 5000 bootstrapping resamples and the $95 \%$ bias-corrected percentile confidence interval (CI) method. The results show that the $95 \%$ CI of H4a, H4c did not straddle zero $(p \leq 0.05)$ (Table 6). This outcome supports $\mathrm{H} 4 \mathrm{a}$ and $\mathrm{H} 4 \mathrm{c}$. According to the results, object-based authenticity (OBA) and interpersonal 
authenticity (EEXA) influence tourist loyalty through perceived value. Since both OBA and EEXA have significant influence on loyalty, perceived value plays a partial mediating role in the process of OBA and EEXA, affecting loyalty. H4b is rejected; it shows that perceived value cannot mediate the relationship between intrapersonal authenticity and loyalty.

Table 6. Mediation hypothesis testing.

\begin{tabular}{ccccccc}
\hline \multirow{2}{*}{ Mediation Hypotheses } & \multicolumn{3}{c}{ Bias-Corrected Percentile } \\
\cline { 2 - 7 } & Estimate & SE Boot & Lower & Upper & $p$ & Result \\
\hline H4a (OBA $\rightarrow$ PV $\rightarrow$ LOY) & 0.125 & 0.034 & 0.068 & 0.203 & 0.000 & Supported \\
H4b (IEXA $\rightarrow$ PV $\rightarrow$ LOY) & 0.010 & 0.026 & -0.044 & 0.063 & 0.696 & Rejected \\
H4c (EEXA $\rightarrow$ PV $\rightarrow$ LOY) & 0.167 & 0.049 & 0.089 & 0.289 & 0.000 & Supported \\
\hline
\end{tabular}

Note: Estimate $=$ Standardized estimate value, $\mathrm{SE}=$ Standardized errors estimated by bootstrapping maximum likelihood approach with 5000 resamples in AMOS. Significant means the value of $p$ is less than 0.05 .

\section{Discussion of Main Findings, Conclusions and Implications}

The aim of this study was to explore the influence mechanism of authenticity, perceived value, and loyalty. First, the study suggested a research model encompassing five constructs to investigate the hypothesized relationship and impact between them. Then, an empirical study was performed with the aim to test and validate the proposed model. The chosen study area was three marine tourism destinations in Zhoushan Archipelago, Southeastern China. Statistical analyses were carried out by using AMOS 24.0 software and the results of these analyses were presented in a detailed way in the previous section.

Based on the presentation of results, the main findings of our study are discussed within the context. First, extant studies tend to consider and approach this conceptexistential authenticity - as a one-dimensional construct $[19,20]$. However, by distinguishing its two sub-dimensions (IEXA and EEXA), our research finds that only interpersonal authenticity (EEXA) can significantly affect perceived value, which indicates that existential authenticity should be analyzed into two dimensions (intrapersonal and interpersonal authenticity), and consequently explored the influence of two dimensions on perceived value separately, which supports the views of previous scholars $[1,7,12]$.

Second, this paper comprehensively explores the influence of three types of authenticity (OBA, IEXA and EEXA) on tourist loyalty, and finds that OBA and EEXA are the main factors affecting tourist loyalty. This finding can be regarded as an improvement of previous researchers [8-10].

Third, the study's findings indicated that perceived value plays a role of partial mediation in the relationship between authenticity and loyalty. More specifically, objectbased authenticity and interpersonal authenticity can influence loyalty through their impact on perceived value. This indicates that authentic tourism objects and positive interpersonal communication can improve tourists' perceived value from a specific experience, thus enhancing their loyalty to a marine tourism destination/site [31,49].

According to these findings, some theoretical contributions and managerial implications can be proposed.

\subsection{Theoretical Contribution}

First, most of the existing literature on authenticity is based on the context of cultural heritage tourism. However, this study is one of the first literatures focusing on the topic of authenticity within the field of marine tourism, which enriches the context of authenticity research.

Second, this paper discusses the relationship between authenticity, perceived value and loyalty in the same research framework, which has rarely been done by previous scholars. On the one hand, the effects of three types of authenticity (OBA, IEXA, and EEXA) on perceived value and loyalty have been examined; on the other hand, the mediating 
effect of perceived value on the relationship between authenticity and loyalty has also been verified. The relevant conclusions improve and expand the existing research.

Finally, this study has explored how authenticity affects tourists' evaluation of tourism site and their willingness to revisit. Therefore, it will serve as a supplement to relevant literature on sustainable marketing of tourist destinations.

\subsection{Managerial Implications}

It is believed that the study's findings are useful to industry practitioners and other stakeholders involved in marine tourism. The factors affecting the authenticity of tourism experience could assist managers and marketers in improving travel experience and in enhancing their loyalty to destination/site.

First, it was revealed that object-based and interpersonal authenticity are two key factors that affect perceived value and loyalty, and tourism managers and marketers can create a high-quality travel experience based on these two elements. On one hand, the authentic representation of tourism objects should be highlighted, especially putting an emphasis on and focusing on their "symbolic meaning". That is to say, the landscapes of marine tourism sites need to represent and reflect the marine history and culture. More importantly, maintaining the authenticity of tourism objects is beneficial to the sustainable use of tourism resources. On the other hand, tourists' emotional experience should be taken seriously into account, and cannot be overlooked. It is suggested that tourists' interpersonal communication is of critical significance to improve their loyalty, and their willingness to revisit marine tourism destinations. Therefore, some maritime-specific activities should be designed and organized to enhance the interaction between tourists and local residents, thus creating a sustainable tourism experience for tourists.

Second, in light of the mediating role of perceived value in the relationship between authenticity and loyalty, it is also important to enhance tourists' perceived value. Therefore, the managers and marketers of marine tourism sites should provide tourists with highquality tourism services in terms of welcome, accommodation and transportation which are conducive to the sustainable operation of tourism destinations.

\subsection{Limitations and Future Research}

This study has some limitations and their acknowledgement could provide pathways for future research endeavors. First, our research instrument could be improved and extended to incorporate some additional variables and items. Second, the research method itself could be combined with qualitative research, and semi-structured interviews with key informants and stakeholders. Variables and items can also be identified through focus group interviews, in-depth interviews, or content analysis of websites, as recommended by previous empirical studies [74,75]. Second, the empirical investigation was conducted in a limited number of sites within one spatial zone. Therefore, findings cannot be generalized to all marine tourism destinations. Other marine tourism destinations in China and other countries also deserve attention because of the heterogeneity and diversity of landscape and other tourist resources and assets. Future research could test the utility and the value of the suggested research model in the context of other countries and regions in order to confirm or contradict findings. Third, future research endeavors could further explore the influence of different types and dimensions of authenticity. A meaningful approach could be to empirically examine the two dimensions of intrapersonal authenticity in other tourism contexts. Likewise, the proposed research model proposed could be improved by considering and analyzing different aspects of perceived value and loyalty, or by adding other variables such as tourists' satisfaction and post-visit behavioral intention.

Author Contributions: Conceptualization, Y.S. and J.X.; methodology, Y.S. and M.S.; software: J.X.; validation, S.S. and M.S.; formal analysis, Y.S. and S.S.; investigation, Y.S. and S.S.; resources, Y.S. and J.X.; data curation, S.S. and J.X.; writing-original draft preparation, Y.S. and S.S.; writing-review and editing, Y.S. and M.S.; visualization, J.X.; supervision, Y.S. and M.S.; project administration, Y.S.; 
funding acquisition, Y.S. and J.X. All authors have read and agreed to the published version of the manuscript.

Funding: This research was supported by National Social Science Foundation of China under grant number 20BH142.

Institutional Review Board Statement: Not applicable.

Informed Consent Statement: Not applicable.

Data Availability Statement: We choose to exclude this statement if the study did not report any data.

Conflicts of Interest: The authors declare no conflict of interest. The funders had no role in the design of the study; in the collection, analyses, or interpretation of data; in the writing of the manuscript, or in the decision to publish the results.

\section{References}

1. Wang, N. Rethinking Authenticity in Tourism Experience. Ann. Tour. Res. 1999, 26, 349-370. [CrossRef]

2. MacCannell, D. Staged authenticity: Arrangements of social space in tourist settings. Am. J. Sociol. 1973, 3, 589-603. [CrossRef]

3. Boorstin, D.J. The Image: A Guide to Pseudo-Events in America; Atheneum: New York, NY, USA, $1964 ;$ p. 106.

4. MacCannell, D. The Tourist: A New Theory of the Leisure Class; Schocken Books: New York, NY, USA, 1976.

5. Culler, J. Semiotics of Tourism. Am. J. Semiot. 1981, 1, 127-140. [CrossRef]

6. Cohen, E. Authenticity and commoditization in tourism. Ann. Tour. Res. 1988, 15, 371-386. [CrossRef]

7. Reisinger, Y.; Steiner, C.J. Reconceptualizing object authenticity. Ann. Tour. Res. 2006, 33, 65-86. [CrossRef]

8. Kolar, T.; Zabkar, V.A. consumer-based model of authenticity: An oxymoron or the foundation of cultural heritage marketing? Tour. Manag. 2010, 31, 652-664. [CrossRef]

9. Zhou, Q.B.; Jie, Z.; Zhang, H.; Ma, J. A structural model of host authenticity. Ann. Tour. Res. 2015, 55, 28-45. [CrossRef]

10. Yi, X.; Fu, X.; Yu, L.; Jiang, L. Authenticity and loyalty at heritage sites: The moderation effect of postmodern authenticity. Tour. Manag. 2018, 67, 411-424. [CrossRef]

11. Kim, H.; Jamal, T. Touristic quest for existential authenticity. Ann. Tour. Res. 2007, 34, 181-201. [CrossRef]

12. Shepherd, R.J. Why Heidegger did not travel: Existential angst, authenticity, and tourist experiences. Ann. Tour. Res. 2015, 52, 60-71. [CrossRef]

13. Vidon, E.S.; Rickly, J.M.; Knudsen, D.C. Wilderness state of mind: Expanding authenticity. Ann. Tour. Res. 2018, 73, 62-70. [CrossRef]

14. Cohen, S.; Cohen, E. New directions in the sociology of tourism. Curr. Issues Tour. 2017, 22, 153-172. [CrossRef]

15. Fu, X. Existential authenticity and destination loyalty: Evidence from heritage tourists. J. Destin Mark. Manag. 2019, 12, 84-94. [CrossRef]

16. Shang, W.; Yuan, Q.; Chen, N. Examining Structural Relationships among Brand Experience, Existential Authenticity, and Place Attachment in Slow Tourism Destinations. Sustainability 2020, 12, 2784. [CrossRef]

17. Knudsen, D.C.; Rickly, J.M.; Vidon, E.S. The fantasy of authenticity: Touring with Lacan. Ann. Tour. Res. 2016, 58, 33-45. [CrossRef]

18. Kirillova, K.; Lehto, X.Y.; Cai, L. Existential Authenticity and Anxiety as Outcomes: The Tourist in the Experience Economy. Int. J. Tour. Res. 2017, 19, 13-26. [CrossRef]

19. Lee, S.; Phau, I.; Hughes, M. Heritage Tourism in Singapore Chinatown: A Perceived Value Approach to Authenticity and Satisfaction. J. Travel. Tour. Mark. 2016, 33, 981-998. [CrossRef]

20. Zhang, S.N.; Li, Y.Q.; Liu, C.H.; Ruan, W.Q. How does authenticity enhance flow experience through perceived value and involvement: The moderating roles of innovation and cultural identity. J. Travel. Tour. Mark. 2019, 36, 711-729. [CrossRef]

21. Tian, D.; Wang, Q.; Law, R.; Zhang, M. Influence of Cultural Identity on Tourists' Authenticity Perception, Tourist Satisfaction, and Traveler Loyalty. Sustainability 2020, 12, 6344. [CrossRef]

22. Lu, T. Perception of community on authenticity of ethnic singing and dancing performance in Jiuzhaigou tourism destination. Tour. Trib. 2007, 22, 89-94.

23. Goulding, C. The commodification of the past, postmodern pastiche, and the search for authentic experiences at contemporary heritage attractions. Eur. J. Mark. 2000, 34, 835-853. [CrossRef]

24. Jensen, U.; Lindberg, F. The Consumption of Tourist Attraction: A Modern, Postmodern and Existential Encounter Perspective. In Interpretive Consumer Research: Paradigms, Methodologies \& Applications; Beckmann, S.C., Elliott, R.C., Eds.; Copenhagen Business School Press: Copenhagen, Denmark, 2001.

25. Salamone, F.A. Authenticity in tourism: The San Angel Inns. Ann. Tour. Res. 1997, 24, 305-321. [CrossRef]

26. Xie, Y.J. Tourism Experience Research-A Phenomenological Perspective; Nankai University Press: Tianjin, China, 2006; pp. 188-230.

27. Su, X. Reconstructing Tradition: Heritage Authentication and Tourism-Related Commodification of the Ancient City of Pingyao. Sustainability 2018, 10, 670. [CrossRef] 
28. Yi, X.; Lin, V.S.; Jin, W.; Luo, Q. The Authenticity of Heritage Sites, Tourists Quest for Existential Authenticity, and Destination Loyalty. J. Travel. Res. 2016, 56, 1032-1048. [CrossRef]

29. Rickly-Boyd, J.M. Authenticity \& aura: A Benjaminian Approach to Tourism. Ann. Tour. Res. 2012, 39, $269-289$.

30. Nguyen, T.H.H. A Reflective-Formative Hierarchical Component Model of Perceived Authenticity. J. Hosp. Tour. Res. 2020, 44, 1211-1234. [CrossRef]

31. Chen, Q.; Huang, R.; Hou, B. Perceived authenticity of traditional branded restaurants (China): Impacts on perceived quality, perceived value, and behavioural intentions. Curr. Issues Tour. 2020, 23, 2950-2971. [CrossRef]

32. Zhou, Y.; Wu, M.; Zhou, Y.; Lan, Y. Theory of "authenticity" and its Comparison in Tourism Study. Tour. Trib. $2007,6,42-47$.

33. Brown, L. Tourism: A catalyst for existential authenticity. Ann. Tour. Res. 2013, 40, 176-190. [CrossRef]

34. Chhabra, D.; Healy, R.; Sills, E. Staged authenticity and heritage tourism. Ann. Tour. Res. 2003, 30, 702-719. [CrossRef]

35. Zhu, Y. Performing heritage: Rethinking authenticity in tourism. Ann. Tour. Res. 2012, 39, 1495-1513. [CrossRef]

36. Moufahima, M.; Lichroub, M. Pilgrimage, consumption and rituals: Spiritual authenticity in a Shia Muslim pilgrimage. Tour. Manag. 2019, 70, 322-332. [CrossRef]

37. Andriotis, K. Genres of heritage authenticity. Denotations from a pilgrimage landscape. Ann. Tour. Res. 2011, 38, 1613-1633. [CrossRef]

38. Belhassen, Y.; Caton, K.; Stewart, W.P. The search for authenticity in the pilgrim experience. Ann. Tour. Res. 2008, 35, 668-689. [CrossRef]

39. Kontogeorgopoulos, N. Finding oneself while discovering others: An existential perspective on volunteer tourism in Thailand. Ann. Tour. Res. 2017, 65, 1-12. [CrossRef]

40. Jiang, Y.; Ramkissoon, H.; Mavondo, F.T.; Feng, S. Authenticity: The Link between Destination Image and Place Attachment. J. Hosp. Mark. Manag. 2016, 26, 105-124. [CrossRef]

41. Zeithaml, V.A. Consumer Perceptions of Price, Quality, and Value: A Means-End Model and Synthesis of Evidence. J. Mark. 1988, 52, 2-22. [CrossRef]

42. Ha, J.; Jang, S.C. Perceived values, satisfaction, and behavioral intentions: The role of familiarity in Korean restaurants. Int. J. Hosp. Manag. 2010, 29, 2-13. [CrossRef]

43. Bajs, I.P. Tourist Perceived Value, Relationship to Satisfaction, and Behavioral Intentions: The Example of the Croatian Tourist Destination Dubrovnik. J. Travel. Res. 2015, 43, 171-189.

44. Paraskevaidis, P.; Andriotis, K. Values of souvenirs as commodities. Tour. Manag. 2015, 48, 1-10. [CrossRef]

45. Prebensen, N.K.; Xie, J. Efficacy of co-creation and mastering on perceived value and satisfaction in tourists' consumption. Tour. Manag. 2017, 60, 166-176. [CrossRef]

46. Sabiote-Ortiz, C.M.; Frias-Jamilena, D.M.; Castaneda-Garcia, J.A. Overall Perceived Value of a Tourism Service Delivered via Different Media: A Cross-Cultural Perspective. J. Travel. Res. 2016, 55, 34-51. [CrossRef]

47. Sánchez, J.; Callarisa, L.; Rodríguez, R.M.; Moliner, M.A. Perceived value of the purchase of a tourism product. Tour. Manag. 2006, 27, 394-409. [CrossRef]

48. Soutar, S.G.N. Consumer perceived value: The development of a multiple item scale. J. Retail. 2001, 77, $203-220$.

49. Fu, Y.; Liu, X.; Wang, Y.; Chao, R.F. How experiential consumption moderates the effects of souvenir authenticity on behavioral intention through perceived value. Tour. Manag. 2018, 69, 356-367. [CrossRef]

50. Oliver, R.L. Whence Consumer Loyalty? J. Mark. 1999, 63, 33-44. [CrossRef]

51. Oliver, R.L. Satisfaction: A Behavioral Perspective on the Consumer; McGraw-Hill: New York, NY, USA, 1997.

52. Zhang, H.; Fu, X.; Cai, L.A.; Lu, L. Destination image and tourist loyalty: A meta-analysis. Tour. Manag. 2014, 40, 213-223. [CrossRef]

53. Chen, C.F.; Chen, F.S. Experience quality, perceived value, satisfaction and behavioral intentions for heritage tourists. Tour. Manag. 2010, 31, 29-35. [CrossRef]

54. Meleddu, M.; Paci, R.; Pulina, M. Repeated behaviour and destination loyalty. Tour. Manag. 2015, 50, 159-171. [CrossRef]

55. Back, K.; Park, S.C. A Brand Loyalty Model Involving Cognitive, Affective, and Conative Brand Loyalty and Customer Satisfaction. J. Hosp. Tour. Res. 2003, 27, 419-435. [CrossRef]

56. Back, K. The Effects of Image Congruence on Customers' Brand Loyalty in the Upper Middle-Class Hotel Industry. J. Hosp. Tour. Res. 2016, 29, 448-467. [CrossRef]

57. Yuksel, A.; Yuksel, F.; Bilim, Y. Destination attachment: Effects on customer satisfaction and cognitive, affective and conative loyalty. Tour. Manag. 2010, 31, 274-284. [CrossRef]

58. Pedersen, P.E.; Nysveen, H.R. Shopbot banking: An exploratory study of customer loyalty effects. Int. J. Bank. Mark. 2001, 19, 146-155. [CrossRef]

59. Mody, M.; Hanks, L. Consumption Authenticity in the Accommodations Industry: The Keys to Brand Love and Brand Loyalty for Hotels and Airbnb. J. Travel. Res. 2020, 59, 173-189. [CrossRef]

60. Lin, Y.C.; Liu, Y.C. Deconstructing the internal structure of perceived authenticity for heritage tourism. J. Sustain. Tour. 2019, 26, 2134-2152. [CrossRef]

61. Nirundon, T.; Robert, W. An Examination of the Role of Beneficial Image in Tourist Destination Selection. J. Travel. Res. 2000, 39, 37-44. 
62. Murphy, P.; Pritchard, M.P.; Smith, B. The destination product and its impact on traveller perceptions. Tour. Manag. 2000, 21, 43-52. [CrossRef]

63. Jang, S.C.; Ha, J.; Park, K. Effects of ethnic authenticity: Investigating Korean restaurant customers in the U.S. Int. J. Hosp. Manag. 2012, 31, 990-1003. [CrossRef]

64. Liu, H.; Li, H.; Dipietro, R.B.; Levitt, J.A. The role of authenticity in mainstream ethnic restaurants: Evidence from an independent full-service Italian restaurant. Int. J. Contemp. Hosp. Manag. 2018, 30, 1035-1053. [CrossRef]

65. Home, R.; Oehen, B.; Ksmayr, A.; Wiesel, J.; Meulen, N.V.D. The Importance of Being Local: The Role of Authenticity in the Concepts Offered by Non-Themed Domestic Restaurants in Switzerland. Sustainability 2020, 12, 3907. [CrossRef]

66. Lee, J.S.; Lee, C.K.; Choi, Y. Examining the Role of Emotional and Functional Values in Festival Evaluation. J. Travel. Res. 2010, 50, 685-696. [CrossRef]

67. Nunnally, J.C. Psychometric theory. Am. Educ. Res. J. 1978, 5, 83.

68. Anderson, J.C.; Gerbing, D.W. Structural equation modeling in practice: A review and recommended two-step approach. Psychol. Bull. 1988, 103, 411-423. [CrossRef]

69. Hair, J.R.J.; Black, W.; Babin, B.; Anderson, R. Multivariate Data Analysis, 7th ed.; Pearson: London, UK, 2009.

70. Bagozzi, R.P. Evaluating Structural Equation Models with Unobservable Variables and Measurement Error: A Comment. J. Mark. Res. 1981, 18, 375-381. [CrossRef]

71. Baumergartner, H.; Homburg, C. Applications of structural equation modeling in marketing and consumer research: A review. Int. J. Res. Mark. 1996, 13, 139-161. [CrossRef]

72. Bollen, K.A. Structural Equations with Latent Variables; John Wiley \& Sons: New York, NY, USA, 1989; pp. $289-308$.

73. Hoyle, R.H. Structural Equation Modeling: Concepts, Issues, and Applications; Sage Publications: Thousand Oaks, CA, USA, 1995.

74. DeVellis, R.F. Scale Development: Theory and Applications, 3rd ed.; Sage Publications: Thousand Oaks, CA, USA, 2012.

75. Na, M.F.; Xie, Y.J.; Gursoy, D. A Study on Destination Experiential Value: Multi-dimensional Analysis and Scale Development. Tour. Trib. 2019, 34, 48-60. 